\title{
Regulation of blood vascular permeability in the skin
}

\author{
Sachiko Ono', Gyohei Egawa ${ }^{1}$ and Kenji Kabashima ${ }^{1,2,3^{*}}$
}

\begin{abstract}
Regulation of blood vessel permeability is essential for the homeostasis of peripheral tissues. This regulation controls the trafficking of plasma contents, including water, vitamins, ions, hormones, cytokines, amyloids, lipoproteins, carrier proteins, and immunoglobulins. The properties of blood vessels vary among tissues based on their structural differences: continuous, fenestrated, or sinusoidal. These three types of blood vessels have different charge and size barrier properties. The anionic luminal glycocalyx layer on endothelial cells establishes the "charge barrier" that repels the attachment of negatively charged blood cells and plasma molecules. In contrast, the "size barrier" of blood vessels largely relies on the interendothelial junctions (IEJs) between endothelial cells, which define the paracellular permeability. As in most peripheral tissues, blood capillaries in the skin are composed of continuous and/or fenestrated blood vessels that have relatively tighter IEJs compared to those in the internal organs. Small vesicles in the capillary endothelium were discovered in the 1950s, and studies have since confirmed that blood endothelial cells transport the plasma contents by endocytosis and subsequent transcytosis and exocytosis - this process is called transcellular permeability. The permeability of blood vessels is highly variable as a result of intrinsic and extrinsic factors. It is significantly elevated upon tissue inflammations as a result of disabled IEJs and increased paracellular permeability due to inflammatory mediators. An increase in transcellular permeability during inflammation has also been postulated. Here, we provide an overview of the general properties of vascular permeability based on our recent observations of murine skin inflammation models, and we discuss its physiological significance in peripheral homeostasis.
\end{abstract}

Keywords: Blood vessel, Permeability, Interendothelial junctions, Paracellular, Transcellular, Skin, Inflammation, Immunoglobulin

\section{Background}

Blood vessels, especially those of microvessels, serve as a semipermeable barrier between blood contents and the tissue, which is much more permeable than epithelial systems. Acting as canals, blood vessels carry cargos with different sizes and charges in plasma to their proper destinations (Fig. 1).

The permeability of blood vessels is composed of two distinct barriers: the charge barrier and the size barrier (reviewed in [1-3]). The luminal glycocalyx layer on endothelial cells establishes the anionic "charge barrier," with some additional roles have been postulated to date (discussed later). The paracellular permeability between

\footnotetext{
* Correspondence: kaba@kuhp.kyoto-u.ac.jp

'Department of Dermatology, Kyoto University Graduate School of Medicine, 54 Shogoin-Kawahara, Sakyo, Kyoto 606-8507, Japan

${ }^{2}$ Singapore Immunology Network (SlgN) and Institute of Medical Biology,

Agency for Science, Technology and Research (A*STAR), Biopolis, Singapore

Full list of author information is available at the end of the article
}

the interendothelial junctions (IEJs) is often responsible for the size barrier, which is regulated by the presence or absence of adherens junctions (AJs) and/or tight junctions (TJs) in the IEJs (reviewed in [1, 4]). However, IEJs are not solely responsible for defining the size barrier; there appears to be a large contribution of basement membranes, fenestrae, and diaphragms [3] (Table 1). In addition to endothelial organization, non-cellular and cellular components surrounding blood endothelial cells, the extracellular matrix ([5], reviewed in [6]), pericytes [7], and immune cells such as perivascular mast cells, may participate in regulating the permeability of blood vessels [8] (Fig. 2). Furthermore, in terms of vesicular transportation through endothelial cells, the transcellular pathway may dominate the paracellular pathway in determining the vascular permeability of selective molecules, especially in vessels with tight IEJs. 


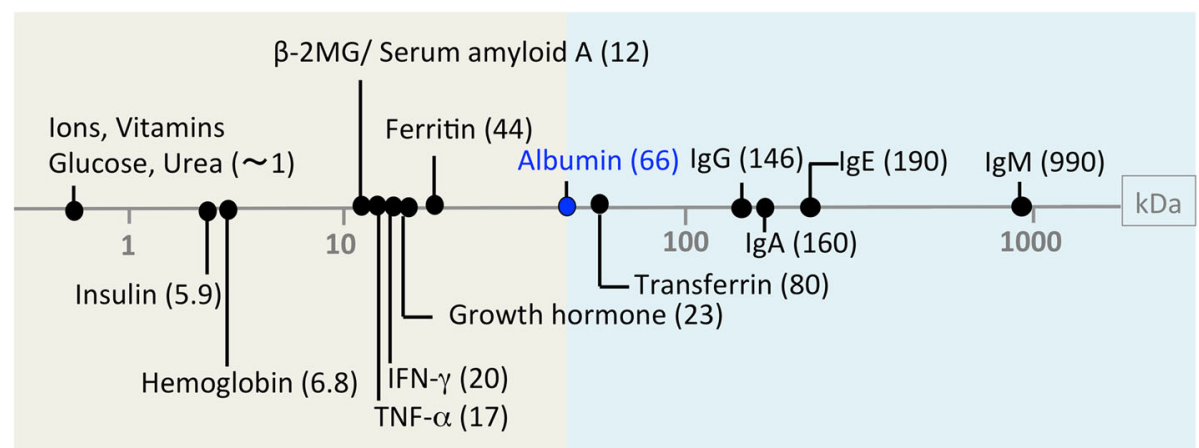

Fig. 1 The molecular weights of representative plasma molecules. $\beta-2 M G$ beta-2 microglobulin, IFN- $\gamma$ interferon- $\gamma$, TNF- $a$ tumor necrosis-a (Modification from a figure in [14]). The background colors discriminate plasma molecules that may (gray) or may not (blue) extravasate via paracellular pathway of the cutaneous blood vessels

Here, we provide an overview of the current knowledge of the permeability of blood vessels. We then cut into the dynamic regulation of blood vascular permeability especially upon inflammation. We also focus on the extravasation of immunoglobulins (Igs), the representative macromolecules in plasma, to the skin, because they may be essential for the homeostasis of cutaneous immune systems not only in terms of host protection but also for the pathogenesis of allergic and autoimmune skin disorders.

\section{Types of blood vessels and their size barriers determine paracellular permeability}

The human body has three types of blood vessels based on their structural differences: continuous (non-fenestrated), fenestrated, and sinusoidal (reviewed in [2]). In brief, blood vessels can first be classified into sinusoidal (discontinuous) or non-sinusoidal by the presence or absence of continuous basement membranes beneath endothelial cells. Non-sinusoidal blood vessels can be

Table 1 Types of blood vessels in various organs with different permeability

\begin{tabular}{|c|c|c|c|c|c|}
\hline \multicolumn{6}{|c|}{ A. Charge barrier [17-23] } \\
\hline Glycocalyx layer & \multicolumn{5}{|c|}{$\begin{array}{l}\text { Anionic mesh-like layer with regular spacing of }<20 \mathrm{~nm} \text { for continuous and fenestrated vessels (irregularly found on sinusoidal } \\
\text { vessels), on both the surface of IEJ clefts and endothelial cells. }\end{array}$} \\
\hline \multicolumn{6}{|c|}{ B. Size barrier (reviewed in [2]) } \\
\hline Types of blood ve & ssels & Types of endothelial cells & $\begin{array}{l}\text { Interendothelial } \\
\text { junctions (IEJS) }\end{array}$ & Representative organs & $\begin{array}{l}\text { Estimated upper limit } \\
\text { for paracellular } \\
\text { transportation [4] }\end{array}$ \\
\hline \multirow[t]{2}{*}{$\begin{array}{l}\text { Continuous } \\
\text { (non-fenestrated) }\end{array}$} & $\begin{array}{l}\text { Continuous } \\
\text { basement } \\
\text { membrane }\end{array}$ & No fenestrae & $\begin{array}{l}\text { Tight junctions and } \\
\text { adherens junctions }\end{array}$ & $\begin{array}{l}\text { Retina [2] } \\
\text { brain, spinal cord [66] } \\
\text { thymus [67] }\end{array}$ & $\begin{array}{l}\text { Determined by IEJs } \\
\text { (TJs) }<1 \mathrm{~nm}\end{array}$ \\
\hline & & & $\begin{array}{l}\text { Adherens junctions } \\
\text { with limited contribution } \\
\text { of tight junctions }\end{array}$ & $\begin{array}{l}\text { skin }[12,13] \\
\text { muscle, heart }[68,69] \\
\text { adipose tissue }[70] \\
\text { lung }[71,72]\end{array}$ & $\begin{array}{l}\text { Determined by IEJs } \\
(\mathrm{AJs})<5 \mathrm{~nm}\end{array}$ \\
\hline \multirow[t]{2}{*}{ Fenestrated } & & $\begin{array}{l}\text { Fenestrated } \\
\text { (with diaphragm) }\end{array}$ & & $\begin{array}{l}\text { skin }[12,13] \\
\text { exocrine glands }[73] \\
\text { kidney (peritubular) }[74] \\
\text { endocrine glands }[73,75,76] \\
\text { intestinal mucosa }[77,78] \\
\text { lymph node }[79,80]\end{array}$ & $\begin{array}{l}\text { Determined by } \\
\text { diaphragm } \\
<6-12 \mathrm{~nm}[81]\end{array}$ \\
\hline & & $\begin{array}{l}\text { Fenestrated (open pores } \\
\text { without diaphragm) }\end{array}$ & & Kidney (glomerulus) $[82,83]$ & $\begin{array}{l}\text { Determined by } \\
\text { glycocalyx } \\
<15 \mathrm{~nm}[2,19]\end{array}$ \\
\hline $\begin{array}{l}\text { Sinusoidal } \\
\text { (discontinuous) }\end{array}$ & $\begin{array}{l}\text { Discontinuous } \\
\text { basement membrane }\end{array}$ & $\begin{array}{l}\text { Fenestrated (with and/or } \\
\text { without diaphragm) }\end{array}$ & & $\begin{array}{l}\text { Liver }[84-86] \\
\text { spleen }[87]\end{array}$ & $\begin{array}{l}<50-280 \mathrm{~nm} \text {, largely } \\
\text { differ among species } \\
<3-5 \mu \mathrm{m}\end{array}$ \\
\hline
\end{tabular}




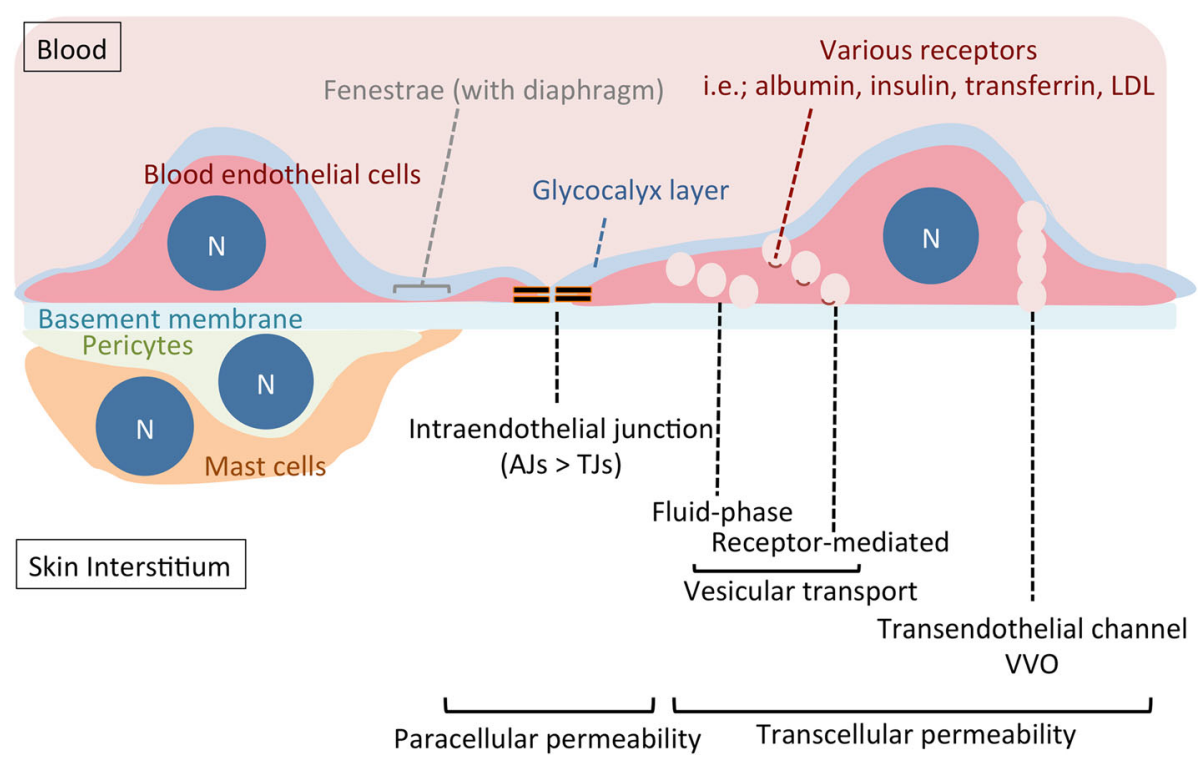

Fig. 2 Integrity of blood vessels in the skin. N nucleus, AJs adherens junction, TJs tight junction, WVO vesiculo-vacuolar organelle, LDL low-density lipoprotein

termed as continuous blood vessels in a broad sense and can be further classified into fenestrated and nonfenestrated (continuous blood vessels in a narrow sense), based on their endothelial types with or without fenestrations. Fenestrated blood vessels can further be subclassified by the existence of a diaphragm [9] (Table 1).

IEJs, the structures connecting adjacent blood endothelial cells, are composed of AJs and TJs. AJs are composed of vascular endothelial (VE)-cadherin complexes with catenin; and TJs are composed of claudins, occludins, and junctional adhesion molecules $[1,4,10]$. In human umbilical vein endothelial cells, TJs represent only approximately $20 \%$ of the total junctional complexes [11]. Therefore, it is generally accepted that IEJs are primary established by AJs in most peripheral blood vessels (reviewed in [4]). In specific continuous vessels, blood endothelial cells are much more firmly adhered to each other with enriched TJs to serve as specialized interfaces such as the blood-brain barrier or the bloodretinal barrier, bringing about low accessibility of plasma contents to these tissues.

The blood vessels in the skin are reportedly composed of continuous (non-fenestrated) and fenestrated blood vessels [12, 13], limiting passive diffusion of albumin, which has the molecular size of $66 \mathrm{kDa}$ (approximately $7 \mathrm{~nm}$ in a diameter), and of dextrans larger than $70 \mathrm{kDa}$ (as discussed later) [14]. This is consistent with the previous studies on other continuous vessels [2, 15]. Taken together, cutaneous blood vessels may act as the size barrier around $70 \mathrm{kDa}$, presumably allowing the passive diffusion of small molecules, including ions, glucose, urea, amino acids, insulin, cytokines, amyloids, and some hormones via the paracellular pathway in the steady state but not of albumin, transferrin, and Igs (Fig. 1). Of note, the size barrier only reflects one aspect of overall vascular permeability because the extravasation of each plasma molecule may be induced by the transcellular and paracellular permeability with variable dependency (Fig. 2).

\section{The charge barrier}

Glycocalyx is a negatively charged continuous coat of proteoglycans, glycosaminoglycans, and absorbed plasma proteins, on the luminal surface of blood endothelial cells [4, 16, 17] (Fig. 2). Its thickness has been reported to range between 20 and $3000 \mathrm{~nm}$ depending on the detection method, vessel types, and the tissues [17-20]. Glycocalyx acts as a primary charge barrier for the transportation of plasma molecules. Several studies using enzymatic procedures that induce shedding or disruption of the glycocalyx layer or neutralize its negative charge have demonstrated the increased vascular permeability to water without affecting the IEJs [20-23].

Glycocalyx can also act as the primary size barrier in fenestrated blood vessels. In these vessels, the diameter of endothelial fenestrations is around $60 \mathrm{~nm}$ irrespective of the presence of a diaphragm, but the physiologically estimated upper limit of the size barrier is smaller than $15 \mathrm{~nm}$ [2] (Table 1). It is assumed that this discrepancy may be due to glycolcalyx occupying the fenestrations [18]. These observations lead to the "fiber matrix" theory, the idea that glycocalyx's fiber mesh-like structure with regular spacing of $20 \mathrm{~nm}$ may regulate vascular permeability [19]. Glycocalyx may modulate the permeability of plasma molecules, and in turn, plasma proteins 
can be an intrinsic part of glycocalyx [3, 24]. In this context, it is interesting to consider that plasma molecules can indirectly regulate the vascular permeability of other plasma molecules. Glycolcalyx can also sense a fluid shear stress and induce endothelial nitric oxide synthesis within endothelial cells to stabilize the barrier function of blood vessels [25].

\section{The drastic increase in vascular permeability upon various cutaneous inflammations}

Both the size and the charge barriers of blood vessels are largely affected by the physiological state of the surrounding tissue interstitium. These changes in permeability were conventionally assessed by an in vitro transwell assay system that measured the flux of variable molecules through the endothelial cell monolayer cultured in transwell chambers under various stimulus agents [26-29]. Despite the utility of the assay, it has frequently been pointed out that this assay system might not reconstitute the actual vascular integrity and permeability in vivo (discussed in [27]). Alternatively, the Miles assay has been widely used to assess vascular permeability in mice [30]. Intravenously administered tracers (such as Evan's blue) bind to albumin, and the accumulation of the tracer in the skin is evaluated after the local administration of stimulants to evoke vascular hyperpermeability. The Miles assay is useful in evaluating gross changes in vascular permeability in vivo but lacks anatomical information, i.e., the site of hyperpermeability in the net of blood vessels or the interaction of endothelial cells with perivascular cells. Furthermore, the subtle extravasation of tracers in the steady state is under the detection limit in the Miles assay.

In addition to these conventional methods, a new intravital evaluation system for vascular permeability in mice using two-photon microscopy has revealed in a more detailed manner how the blood vascular permeability is dynamically regulated in vivo in the skin [14]. By the intravenous administration of different sizes of fluorescein-conjugated dextrans (20 to $2000 \mathrm{kDa}$ ), it was clearly visualized that the passive diffusion, which may reflect the paracellular transportation, occurs only when dextrans are smaller than $70 \mathrm{kDa}$. When fluoresceinconjugated bovine albumin (molecule size $66 \mathrm{kDa}$ ) was administered intravenously, the majority seemed to be retained in the blood. A gradual extravasation was, however, observed within $1 \mathrm{~h}$ after an injection of albumin but not for $70 \mathrm{kDa}$ dextrans. This may reflect the different regulation of the transcellular transportation of albumin and dextran with similar size. The same in vivo system also clarified the site of vascular hyperpermeability induced in both type I and type IV allergic cutaneous inflammation. Upon inflammation, the size limitation for plasma molecules was abolished, allowing the immediate leakage of up to $2000 \mathrm{kDa}$ dextrans to the skin interstitium. This leakage was selectively induced in the postcapillary venules. This corresponded to the previous assumption that postcapillary venules are the specific site of vascular leakage in inflammation. The physiological barrier of the postcapillary venules seems intrinsically sensitive and vulnerable to inflammation, due to abundant receptors for chemical mediators such as histamine and bradykinin [31, 32], less-abundant TJs [33], and low coverage rate by pericytes of these vessels [34]. Numerous chemical mediators, which are released upon inflammation, can lead to diminishment of AJs and the contraction of blood endothelial cells that lead to the formation of IEJ gaps in postcapillary venules. The molecular detail of underlying mechanism for the dysregulation of paracellular permeability is discussed in other reviews [4]. In addition to vascular leakage, postcapillary venules can also serve as the specific site of leukocyte infiltration and inflammatory cell gathering, which is essential for immune responses in the skin [35-38].

As discussed later, the transcellular pathway might play a central role in the extravasation of plasma macromolecules in the steady state. It is of note that the increase in the transcellular transportation of albumin due to increased caveolae function has also been demonstrated in inflammation [39]. Furthermore, the regularity of glycocalyx is disrupted upon inflammation, resulting in irregular thickened layers and gaps between them. Clustering of glycocalyx induced by inflammation can also activate intracellular signals and provoke cytoskeletal reorganization that leads to barrier dysfunction. This change in glycocalyx structures may also contribute to the elevation of permeability, although this appears to be ignored in recent studies. Overall, the changes in the paracellular permeability, the transcellular permeability, and the charge barrier can all participate in gross increase in vascular permeability upon inflammation.

\section{The increase in immunoglobulin $\mathrm{G}$ extravasation to the skin upon inflammation}

As mentioned in the previous sections, the drastic increase in vascular permeability might allow the extravasation of plasma contents, including macromolecules. Among them, here, we focus on the regulation of IgG and IgE extravasation in the skin because they may play important roles in the terms of protective and pathological immune reactions in the skin.

Historically, IgG kinetics has mostly been studied in the intestinal epithelia or the placenta in view of maternal-to-neonatal/fetal IgG passage. The necessity of the neonatal $\mathrm{Fc} \gamma$ receptor in epithelial cells and trophoblasts has well been established; however, few studies have examined IgG kinetics at the blood vessel walls [40-45]. The molecular weight of IgG is approximately 
$150 \mathrm{kDa}$ (Fig. 1). It was thus presumed that the extravasation of IgGs is tightly regulated in the steady state.

Recent observation using a murine pemphigus model, which is a representative model for autoantibody-related disorders in the skin, revealed that variable local inflammation, such as ultraviolet B irradiation or the topical application of irritants to the skin, enhanced autoantibody deposition in the skin [36]. This increase in autoantibody deposition in the skin leads to exacerbated skin manifestation in the murine pemphigus model. The human body is frequently exposed to external stimuli such as frictions, heat, and the sunlight, which can elicit minor local inflammation. Therefore, IgG distribution in the periphery might be largely influenced by external circumstances. Indeed, it is well known that IgG deposition in the epidermal basement membrane is more frequently detected in sunexposed sites in patients with systemic lupus erythematosus. In view of host protection, enhanced IgG recruitment into the inflammatory site would be important for neutralization of invading pathogens.

Despite the strict regulation, constitutive IgG extravasation to the tissue parenchyma in the steady state appeared to exist [36], and the same observation was made for albumin. This homeostatic extravasation of plasma macromolecules may rely on transcellular permeability (Table 2).

\section{Importance of transcellular permeability}

Conventionally, it is considered that there are two different types of transcellular pathway: receptor-mediated transcytosis and non receptor-mediated bulk-phase transcytosis (often called "fluid-phase" transcytosis) [27, 46]
(Fig. 2). In this review, we do not discuss the transendothelial channels or vesiculo-vacuolar organelles [47, 48]. Plasma molecules those are smaller than the size barrier of the blood vessels $(<70 \mathrm{kDa})$, like insulin, might be able to extravasate in both paracellular and transcellular pathways. However, the transporting efficiency is reportedly much higher in paracellular transportation [49, 50]. Plasma macromolecules that are larger than the size barrier of the blood vessels $(>70 \mathrm{kDa})$ might extravasate by either fluid-phase or receptor-mediated transcytosis; however, its balance in vivo for most macromolecules has not been elucidated.

The transcellular permeability of albumin has extensively been studied and found to be largely dependent on the receptor-mediated transcytosis via gp60 in caveolae [51-53]. Even for albumin, to what extent fluidphase transcytosis contributes to the overall albumin extravasation remains undefined. Furthermore, in fluidphase transcytosis, it is believed that the selectivity of molecules might exist, due to their size and charge. Collectively, the mechanism of transcellular transportation remains to be elucidated for most plasma molecules. The proposed routes for the extravasation of plasma molecules are shown in Table 2.

In epithelial cells, the transcellular pathway is initiated by endocytosis [27]. Therefore, it might also be important to define the way of endocytosis of each molecule to understand the mechanism of transcytosis in blood endothelial cells. Endocytosis can define the destinations of the contents, i.e., to lysosomal degradation, to recycling, or to the transcellular pathway $[40-42,54,55]$

Table 2 Transportation of plasma contents in the steady state

\begin{tabular}{|c|c|c|c|}
\hline Routes & \multicolumn{3}{|l|}{ Molecules } \\
\hline Paracellular pathway & \multicolumn{3}{|c|}{ Water molecules <3 nm molecular radius (i.e., urea, amino acids, glucose, ions) } \\
\hline \multirow[t]{8}{*}{ Transcellular pathway } & Aquaporin channels & & Water (up to $40 \%$ of total hydraulic pathway) \\
\hline & \multirow[t]{2}{*}{ Fluid-phase } & Caveolae & $\begin{array}{l}\text { Albumin }[27,46] \\
\text { intact native, acetylated and oxidized LDL }[88,89] \\
\text { IgG }[44] \\
\text { transferrin and iron }[90]\end{array}$ \\
\hline & & Undetermined & $\begin{array}{l}\text { IgG (bound to FcRn in endosomes after } \\
\text { fluid-phase endocytosis }[40,41,43,49] \text { ) }\end{array}$ \\
\hline & \multirow[t]{3}{*}{ Receptor-mediated } & Caveolae & $\begin{array}{l}\text { Albumin (via gp60 receptor) [50-52] } \\
\text { insulin (via unknown receptor) [49] }\end{array}$ \\
\hline & & Clathrin & $\begin{array}{l}\text { Insulin }[91] \\
\text { transferrin and iron (via transferrin receptor }[92,93] \text { ) } \\
\text { gonadotrophin (via gonadotropin receptor }[94] \text { ) }\end{array}$ \\
\hline & & $\begin{array}{l}\text { Undetermined } \\
\text { carrier vesicle }\end{array}$ & $\begin{array}{l}\text { IgG (via FcRn or FcyR2b }[45,95,96]) \\
\text { LDL (via LDL receptor }[97]) \\
\text { insulin (via insulin receptor [98]) }\end{array}$ \\
\hline & \multicolumn{3}{|c|}{ Transendothelial channels } \\
\hline & \multicolumn{3}{|c|}{ Vesiculo-vacuolar organelles } \\
\hline $\begin{array}{l}\text { Direct probing by non-endothelial } \\
\text { cells over blood vessels }\end{array}$ & \multicolumn{3}{|c|}{ IgE (via FcعRl by mast cells) [58] } \\
\hline
\end{tabular}


(discussed in [51]). Various forms of endocytosis by eukaryotic cells have been found to date, including phagocytosis, macropinocytosis, clathrin-mediated endocytosis, clathrin-independent caveolae-mediated endocytosis, and newly defined clathrin-independent non-caveolar endocytosis [56, 57]. Because caveolae are abundantly observed in blood endothelial cells [50], it is sometimes oversimply stated that both fluid-phase transcytosis and receptormediated transcytosis is mediated by caveolae. However, the abundance of caveolae can vary widely among blood vessels in different tissues [27, 46]. Some studies have suggested the possibility of endocytic pathways other than caveolae in blood endothelial cells (Table 2), but we believe that the actual contribution of various endocytic vesicles on transcellular transportation should be more rigorously explored. In addition to investigating the transcellular route for each macromolecule, their relation to intracellular membrane organelles, such as early endosomes, sorting endosomes, or lysosomes, is also essential in order to understand their final destination. Transcellular permeability is a key issue that requires further research to improve our understanding of vascular homeostasis.

\section{Another unique style of molecular extravasation in the skin-immunoglobulin $E$}

A unique extravasation mechanism of IgE in the skin has recently been demonstrated using an in vivo imaging technique [58]. Mast cells are abundantly located in the skin along the blood vessels [8]. Mast cells are best known as the effector cells of IgE-mediated allergic responses, such as allergic dermatitis and urticaria. Under crosslinking of high-affinity IgE receptors on their surface by specific antigens, mast cells are activated and release proinflammatory molecules, including histamine, leading to vascular hyperpermeability. Intriguingly, recent studies have demonstrated that perivascular mast cells capture blood-circulating IgE by extending their processes across the vessel wall in the steady state [58]. Because the plasma concentration of IgE is significantly lower compared to other Igs and proteins, the way in which mast cells probe and capture IgE by their surface high-affinity IgE receptor (FceRI) appears to be strategic.

No studies have properly assessed the transcellular transportion of IgE, IgA, and IgM via blood endothelial cells. In addition, low-affinity IgE receptors (CD23) or polymeric Ig receptors in epithelial cells have been reported responsible for the transcellular transportation of IgE or IgA and IgM [59-63]. Discriminating the difference between endothelial systems and epithelial systems would reveal the characteristic nature of the blood-tissue interface.

\section{Conclusions}

The regulation of blood vessel permeability is important for tissue homeostasis and has attracted the attention of vascular biologists for decades. Considering that nanoparticles [64], antibody-based biologics, or immune checkpoint inhibitors [65] are globally accepted as promising therapeutic tools for autoimmune disorders and various cancers, the basic insight into the kinetics of micro- and macromolecules at the blood-tissue interface would provide a practical clinical information. By employing accumulated knowledge and well-established conventional methods, the in vivo techniques introduced in this review to finely evaluate blood vascular permeability would enable an enhanced understanding of this physical process.

\section{Abbreviations}

AJs: Adherens junctions; IEJs: Interendothelial junctions; Ig: Immunoglobulin; TJs: Tight junctions

\section{Acknowledgements}

None.

\section{Funding}

This work was supported by the JSPS KAKENHI (263395), Grants-in-Aid for Scientific Research 15H05790, 15H1155, 15K15417, Japan Science and

Technology Agency, Precursory Research for Embryonic Science and Technology (PRESTO) (16021031300), and Japan Agency for Medical Research and Development (AMED) (16ek0410011h0003,

16he0902003h0002).

Availability of data and materials

Not applicable.

Authors' contributions

OS and GE drafted the manuscript. KK completed the manuscript. All authors read and approved the final manuscript.

Competing interests

The authors declare that they have no competing interests.

Ethics approval and consent to participate

Not applicable.

\section{Publisher's Note}

Springer Nature remains neutral with regard to jurisdictional claims in published maps and institutional affiliations.

\section{Author details}

'Department of Dermatology, Kyoto University Graduate School of Medicine, 54 Shogoin-Kawahara, Sakyo, Kyoto 606-8507, Japan. ${ }^{2}$ Singapore

Immunology Network (SIgN) and Institute of Medical Biology, Agency for Science, Technology and Research (A*STAR), Biopolis, Singapore. ${ }^{3}$ PRESTO, Japan Science and Technology Agency, Saitama, Japan.

Received: 30 January 2017 Accepted: 25 April 2017

Published online: 10 July 2017

\section{References}

1. Mehta D, Malik AB. Signaling mechanisms regulating endothelial permeability. Physiol Rev. 2006:86:279-367.

2. Sarin H. Physiologic upper limits of pore size of different blood capillary types and another perspective on the dual pore theory of microvascular permeability. J Angiogenes Res. 2010;2:14. 
3. Squire JM, Chew M, Nneji G, Neal C, Barry J, Michel C. Quasi-periodic substructure in the microvessel endothelial glycocalyx: a possible explanation for molecular filtering? J Struct Biol. 2001;136:239-55.

4. Komarova Y, Malik AB. Regulation of endothelial permeability via paracellular and transcellular transport pathways. Annu Rev Physiol. 2010;72:463-93.

5. Qiao RL, Wang HS, Yan W, Odekon LE, Del Vecchio PJ, Smith TJ, et al. Extracellular matrix hyaluronan is a determinant of the endothelial barrier. Am J Physiol. 1995;269:C103-109.

6. Kalluri R. Basement membranes: structure, assembly and role in tumour angiogenesis. Nat Rev Cancer. 2003;3:422-33.

7. Armulik A, Genove G, Mae M, Nisancioglu MH, Wallgard E, Niaudet C, et al. Pericytes regulate the blood-brain barrier. Nature. 2010;468:557-61.

8. Dudeck A, Dudeck J, Scholten J, Petzold A, Surianarayanan S, Kohler A, et al Mast cells are key promoters of contact allergy that mediate the adjuvant effects of haptens. Immunity. 2011;34:973-84.

9. Stan RV. Endothelial stomatal and fenestral diaphragms in normal vessels and angiogenesis. J Cell Mol Med. 2007;11:621-43.

10. González-Mariscal L, Betanzos A, Nava P, Jaramillo BE. Tight junction proteins. Prog Biophys Mol Biol. 2003;81:1-44.

11. Wojciak-Stothard B, Potempa S, Eichholtz T, Ridley AJ. Rho and Rac but not Cdc42 regulate endothelial cell permeability. J Cell Sci. 2001;114:1343-55.

12. Takada M, Hattori S. Presence of fenestrated capillaries in the skin. Anat Rec. 1972;173:213-9.

13. Imayama S. Scanning and transmission electron microscope study on the terminal blood vessels of the rat skin. J Invest Dermatol. 1981;76:151-7.

14. Egawa G, Nakamizo S, Natsuaki Y, Doi H, Miyachi Y, Kabashima K. Intravital analysis of vascular permeability in mice using two-photon microscopy. Sci Rep. 2013;3:1932.

15. Predescu D, Vogel SM, Malik AB. Functional and morphological studies of protein transcytosis in continuous endothelia. Am J Physiol Lung Cell Mol Physiol. 2004;287:L895-901.

16. Vink H, Duling BR. Capillary endothelial surface layer selectively reduces plasma solute distribution volume. Am J Physiol Heart Circ Physiol. 2000; 278:H285-289.

17. Pries AR, Secomb TW, Gaehtgens P. The endothelial surface layer. Pflugers Arch. 2000:440:653-66.

18. Luft JH. Fine structures of capillary and endocapillary layer as revealed by ruthenium red. Fed Proc. 1966;25:1773-83.

19. Haldenby KA, Chappell DC, Winlove CP, Parker KH, Firth JA. Focal and regional variations in the composition of the glycocalyx of large vessel endothelium. J Vasc Res. 1994;31:2-9.

20. Huxley $\mathrm{VH}$, Williams DA. Role of a glycocalyx on coronary arteriole permeability to proteins: evidence from enzyme treatments. Am J Physiol Heart Circ Physiol. 2000;278:H1177-1185.

21. Lum H, Malik AB. Regulation of vascular endothelial barrier function. Am J Physiol. 1994;267:L223-241.

22. Desjardins C, Duling BR. Heparinase treatment suggests a role for the endothelial cell glycocalyx in regulation of capillary hematocrit. Am J Physiol. 1990;258:H647-654.

23. Sunnergren KP, Fairman RP, deBlois GG, Glauser FL. Effects of protamine, heparinase, and hyaluronidase on endothelial permeability and surface charge. J Appl Physiol (1985). 1987;63:1987-92.

24. Schneeberger EE, Mccormack JA, Hamelin M. Interaction of circulating proteins with pulmonary endothelial glycocalyx and its effect on endothelial permeability. J Cell Biol. 1983;97:A476-6.

25. Florian JA, Kosky JR, Ainslie K, Pang ZY, Dull RO, Tarbell JM. Heparan sulfate proteoglycan is a mechanosensor on endothelial cells. Circ Res. 2003:93:E136-42

26. Albelda SM, Sampson PM, Haselton FR, McNiff JM, Mueller SN, Williams SK, et al. Permeability characteristics of cultured endothelial cell monolayers. J Appl Physiol (1985). 1988;64:308-22.

27. Tuma P, Hubbard AL. Transcytosis: crossing cellular barriers. Physiol Rev. 2003:83:871-932.

28. Cooper JA, Del Vecchio PJ, Minnear FL, Burhop KE, Selig WM, Garcia JG, et al. Measurement of albumin permeability across endothelial monolayers in vitro. J Appl Physiol (1985). 1987;62:1076-83.

29. Kluger MS, Clark PR, Tellides G, Gerke V, Pober JS. Claudin-5 controls intercellular barriers of human dermal microvascular but not human umbilical vein endothelial cells. Arterioscler Thromb Vasc Biol. 2013;33:489-500.

30. Nagy JA, Benjamin L, Zeng HY, Dvorak AM, Dvorak HF. Vascular permeability, vascular hyperpermeability and angiogenesis. Angiogenesis. 2008;11:109-19.
31. Heltianu C, Simionescu M, Simionescu N. Histamine receptors of the microvascular endothelium revealed in situ with a histamine-ferritin conjugate: characteristic high-affinity binding sites in venules. J Cell Biol. 1982;93:357-64.

32. Simionescu N, Heltianu C, Antohe F, Simionescu M. Endothelial cell receptors for histamine. Ann N Y Acad Sci. 1982:401:132-49.

33. Bazzoni G, Dejana E. Endothelial cell-to-cell junctions: molecular organization and role in vascular homeostasis. Physiol Rev. 2004;84:869-901.

34. Armulik A, Genove G, Betsholtz C. Pericytes: developmental, physiological, and pathological perspectives, problems, and promises. Dev Cell. 2011;21: 193-215.

35. Natsuaki Y, Egawa G, Nakamizo S, Ono S, Hanakawa S, Okada T, et al. Perivascular leukocyte clusters are essential for efficient activation of effector T cells in the skin. Nat Immunol. 2014;15:1064-9.

36. Ono S, Egawa G, Kitoh A, Dainichi T, Otsuka A, Nakajima S, et al. Local inflammation exacerbates cutaneous manifestations in a murine autoimmune pemphigus model. J Allergy Clin Immunol. 2017. [in press].

37. Ono S, Kabashima K. Proposal of inducible skin-associated lymphoid tissue (iSALT). Exp Dermatol. 2015:24:630-1.

38. Ono S, Kabashima K. Novel insights into the role of immune cells in skin and inducible skin-associated lymphoid tissue (iSALT). Allergo J. 2015:24:18-27.

39. Hu G, Vogel SM, Schwartz DE, Malik AB, Minshall RD. Intercellular adhesion molecule-1-dependent neutrophil adhesion to endothelial cells induces caveolae-mediated pulmonary vascular hyperpermeability. Circ Res. 2008; 102:e120-131.

40. Ober RJ, Martinez C, Lai X, Zhou J, Ward ES. Exocytosis of IgG as mediated by the receptor. FcRn: an analysis at the single-molecule level. Proc Natl Acad Sci U S A. 2004:101:11076-81.

41. Ober RJ, Martinez C, Vaccaro C, Zhou J, Ward ES. Visualizing the site and dynamics of IgG salvage by the MHC class I-related receptor, FcRn. J Immunol. 2004;172:2021-9.

42. Ward ES, Zhou J, Ghetie V, Ober RJ. Evidence to support the cellular mechanism involved in serum IgG homeostasis in humans. Int Immunol. 2003;15:187-5

43. Antohe F, Radulescu L, Gafencu A, Ghetie V, Simionescu M. Expression of functionally active FcRn and the differentiated bidirectional transport of lgG in human placental endothelial cells. Hum Immunol. 2001;62:93-105.

44. Leach L, Eaton BM, Firth JA, Contractor SF. Uptake and intracellular routing of peroxidase-conjugated immunoglobulin-G by the perfused human placenta. Cell Tissue Res. 1990;261:383-8.

45. Gafencu A, Heltianu C, Burlacu A, Hunziker W, Simionescu M. Investigation of lgG receptors expressed on the surface of human placental endothelial cells. Placenta. 2003:24:664-76.

46. Simionescu N. Cellular aspects of transcapillary exchange. Physiol Rev. 1983; 63:1536-79.

47. Feng D, Nagy JA, Hipp J, Dvorak HF, Dvorak AM. Vesiculo-vacuolar organelles and the regulation of venule permeability to macromolecules by vascular permeability factor, histamine, and serotonin. J Exp Med. 1996;183:1981-6.

48. Kohn S, Nagy JA, Dvorak HF, Dvorak AM. Pathways of macromolecular tracer transport across venules and small veins - structural basis for the hyperpermeability of tumor blood-vessels. Lab Invest. 1992;67:596-607.

49. Bendayan M, Rasio EA. Transport of insulin and albumin by the microvascular endothelium of the rete mirabile. J Cell Sci. 1996:109:1857-64.

50. Bendayan M. Morphological and cytochemical aspects of capillary permeability. Microsc Res Tech. 2002:57:327-49.

51. Ghitescu L, Fixman A, Simionescu M, Simionescu N. Specific binding sites for albumin restricted to plasmalemmal vesicles of continuous capillary endothelium: receptor-mediated transcytosis. J Cell Biol. 1986;102:1304-11.

52. Milici AJ, Watrous NE, Stukenbrok H, Palade GE. Transcytosis of albumin in capillary endothelium. J Cell Biol. 1987;105:2603-12.

53. Minshall RD, Tiruppathi C, Vogel SM, Niles WD, Gilchrist A, Hamm HE, et al. Endothelial cell-surface gp60 activates vesicle formation and trafficking via G(i)-coupled Src kinase signaling pathway. J Cell Biol. 2000;150:1057-70.

54. Schnitzer JE, Bravo J. High affinity binding, endocytosis, and degradation of conformationally modified albumins. Potential role of gp30 and gp18 as novel scavenger receptors. J Biol Chem. 1993;268:7562-70.

55. Kim MJ, Dawes J, Jessup W. Transendothelial transport of modified lowdensity lipoproteins. Atherosclerosis. 1994;108:5-17.

56. Howes MT, Kirkham M, Riches J, Cortese K, Walser PJ, Simpson F, et al. Clathrin-independent carriers form a high capacity endocytic sorting system at the leading edge of migrating cells. J Cell Biol. 2010;190:675-91. 
57. Conner SD, Schmid SL. Regulated portals of entry into the cell. Nature. 2003; 422:37-44.

58. Cheng LE, Hartmann K, Roers A, Krummel MF, Locksley RM. Perivascular mast cells dynamically probe cutaneous blood vessels to capture immunoglobulin E. Immunity. 2013;38:166-75.

59. Li H, Nowak-Wegrzyn A, Charlop-Powers Z, Shreffler W, Chehade M, Thomas $\mathrm{S}$, et al. Transcytosis of IgE-antigen complexes by CD23a in human intestinal epithelial cells and its role in food allergy. Gastroenterology. 2006;131:47-58.

60. Palaniyandi S, Liu X, Periasamy S, Ma A, Tang J, Jenkins M, et al. Inhibition of CD23-mediated IgE transcytosis suppresses the initiation and development of allergic airway inflammation. Mucosal Immunol. 2015;8:1262-74.

61. Brown WR, Isobe K, Nakane PK, Pacini B. Studies on translocation of immunoglobulins across intestinal epithelium. IV. Evidence for binding of $\lg A$ and $\lg M$ to secretory component in intestinal epithelium. Gastroenterology. 1977;73:1333-9.

62. Richardson JM, Kaushic C, Wira CR. Polymeric immunoglobin (Ig) receptor production and IgA transcytosis in polarized primary cultures of mature rat uterine epithelial cells. Biol Reprod. 1995;53:488-98.

63. Stadtmueller BM, Huey-Tubman KE, Lopez CJ, Yang Z, Hubbell WL, Bjorkman PJ. The structure and dynamics of secretory component and its interactions with polymeric immunoglobulins. Elife. 2016;5:e10640.

64. Davis ME, Chen ZG, Shin DM. Nanoparticle therapeutics: an emerging treatment modality for cancer. Nat Rev Drug Discov. 2008;7:771-82.

65. Pardoll DM. The blockade of immune checkpoints in cancer immunotherapy. Nat Rev Cancer. 2012;12:252-64.

66. Abbott NJ, Ronnback L, Hansson E. Astrocyte-endothelial interactions at the blood-brain barrier. Nat Rev Neurosci. 2006;7:41-53.

67. Raviola E, Karnovsky MJ. Evidence for a blood-thymus barrier using electronopaque tracers. J Exp Med. 1972;136: 466- +

68. Ward BJ, Bauman KF, Firth JA. Interendothelial junctions of cardiac capillaries in rats-their structure and permeability properties. Cell Tissue Res. 1988;252:57-66.

69. Aird WC. Phenotypic heterogeneity of the endothelium I. Structure, function, and mechanisms. Circ Res. 2007;100:158-73.

70. Williamson JR. Adipose tissue - morphological changes associated with lipid mobilization. J Cell Biol. 1964;20: 57-\&.

71. Schneeberger EE. The permeability of the alveolar-capillary membrane to ultrastructural protein tracers. Ann N Y Acad Sci. 1974;221:238-43.

72. Stevens T, Phan S, Frid MG, Alvarez D, Herzog E, Stenmark KR. Lung vascular cell heterogeneity: endothelium, smooth muscle, and fibroblasts. Proc Am Thorac Soc. 2008:5:783-91.

73. Henderson JR, Moss MC. A morphometric study of the endocrine and exocrine capillaries of the pancreas. Q J Exp Physiol. 1985;70:347-56.

74. Deen WM, Ueki IF, Brenner BM. Permeability of renal peritubular capillaries to neutral dextrans dextrans and endogenous albumin. Am J Physiol. 1976; 231:283-91.

75. Farquhar MG. Fine structure and function in capillaries of the anterior pituitary gland. Angiology. 1961;12:270-92.

76. Ekholm R, Sjostrand FS. The ultrastructural organization of the mouse thyroid gland. J Ultrastruct Res. 1957;1:178-99.

77. Milici AJ, Bankston PW. Fetal and neonatal rat intestinal capillaries: permeability to carbon, ferritin, hemoglobin, and myoglobin. Am J Anat. 1982;165:165-86.

78. Milici AJ, Bankston PW. Fetal and neonatal rat intestinal capillaries: a TEM study of changes in the mural structure. Am J Anat. 1981;160:435-48.

79. Gretz JE, Norbury CC, Anderson AO, Proudfoot AEl, Shaw S. Lymph-borne chemokines and other low molecular weight molecules reach high endothelial venules via specialized conduits while a functional barrier limits access to the lymphocyte microenvironments in lymph node cortex. J Exp Med. 2000;192:1425-39.

80. Rantakari P, Auvinen K, Jappinen N, Kapraali M, Valtonen J, Karikoski M, et al. The endothelial protein PLVAP in lymphatics controls the entry of lymphocytes and antigens into lymph nodes (vol 16, pg 386, 2015). Nat Immunol. 2015;16:544-4.

81. Stan RV, Tse D, Deharvengt SJ, Smits NC, Xu Y, Luciano MR, et al. The diaphragms of fenestrated endothelia: gatekeepers of vascular permeability and blood composition. Dev Cell. 2012;23:1203-18.

82. Caulfield JP, Farquhar MG. The permeability of glomerular capillaries to graded dextrans. Identification of the basement membrane as the primary filtration barrier. J Cell Biol. 1974;63:883-903.

83. Avasthi PS, Koshy V. The anionic matrix at the rat glomerular endothelial surface. Anat Rec. 1988;220:258-66.
84. Snoeys J, Lievens J, Wisse E, Jacobs F, Duimel H, Collen D, et al. Species differences in transgene DNA uptake in hepatocytes after adenoviral transfer correlate with the size of endothelial fenestrae. Gene Ther. 2007;14:604-12.

85. Wisse E, Jacobs F, Topal B, Frederik P, De Geest B. The size of endothelial fenestrae in human liver sinusoids: implications for hepatocyte-directed gene transfer. Gene Ther. 2008;15:1193-9.

86. Naito M, Wisse E. Filtration effect of endothelial fenestrations on chylomicron transport in neonatal rat liver sinusoids. Cell Tissue Res. 1978;190:371-82.

87. Chen LT. Microcirculation of spleen —open or closed circulation. Science. 1978;201:157-9.

88. Sun SW, Zu XY, Tuo QH, Chen LX, Lei XY, Li K, et al. Caveolae and caveolin-1 mediate endocytosis and transcytosis of oxidized low density lipoprotein in endothelial cells. Acta Pharmacol Sin. 2010;31:1336-42.

89. Vasile $\mathrm{E}$, Simionescu M, Simionescu N. Visualization of the binding, endocytosis, and transcytosis of low-density lipoprotein in the arterial endothelium in situ. J Cell Biol. 1983;96:1677-89.

90. Holash JA, Harik SI, Perry G, Stewart PA. Barrier properties of testis microvessels. Proc Natl Acad Sci U S A. 1993;90:11069-73.

91. Azizi PM, Zyla RE, Guan S, Wang C, Liu J, Bolz SS, et al. Clathrin-dependent entry and vesicle-mediated exocytosis define insulin transcytosis across microvascular endothelial cells. Mol Biol Cell. 2015;26:740-50.

92. Crowe A, Morgan EH. Iron and transferrin uptake by brain and cerebrospinal fluid in the rat. Brain Res. 1992;592:8-16.

93. Roberts R, Sandra A, Siek GC, Lucas JJ, Fine RE. Studies of the mechanism of iron transport across the blood-brain barrier. Ann Neurol. 1992;32(Suppl): S43-50.

94. Ghinea N, Milgrom E. A new function for the LH/CG receptor: transcytosis of hormone across the endothelial barrier in target organs. Semin Reprod Med. 2001;19:97-101.

95. Takizawa T, Anderson CL, Robinson JM. A novel Fc gamma R-defined. IgGcontaining organelle in placental endothelium. J Immunol. 2005;175:2331-9.

96. Borvak J, Richardson J, Medesan C, Antohe F, Radu C, Simionescu M, et al. Functional expression of the $\mathrm{MHC}$ class I-related receptor, FCRn, in endothelial cells of mice. Int Immunol. 1998;10:1289-98.

97. Dehouck B, Fenart L, Dehouck MP, Pierce A, Torpier G, Cecchelli R. A new function for the LDL receptor: transcytosis of LDL across the blood-brain barrier. J Cell Biol. 1997;138:877-89.

98. Pardridge WM, Kang YS, Buciak JL, Yang J. Human insulin receptor monoclonal antibody undergoes high affinity binding to human brain capillaries in vitro and rapid transcytosis through the blood-brain barrier in vivo in the primate. Pharm Res. 1995;12:807-16.

\section{Submit your next manuscript to BioMed Central and we will help you at every step:}

- We accept pre-submission inquiries

- Our selector tool helps you to find the most relevant journal

- We provide round the clock customer support

- Convenient online submission

- Thorough peer review

- Inclusion in PubMed and all major indexing services

- Maximum visibility for your research

Submit your manuscript at www.biomedcentral.com/submit
Biomed Central 